\title{
Seasonal Incidence of Fruit Fly, Bactrocera cucurbitae on Bottle Gourd and their Correlation with Abiotic Factors
}

\author{
D. S. Meena ${ }^{1 *}$, V. S. Acharya ${ }^{1}$ and Dinesh Kumar ${ }^{2}$ \\ ${ }^{1}$ Department of Entomology, ${ }^{2}$ College of Agriculture, Department of Soil Science and \\ Agricultural Chemistry, S.K. Rajasthan Agricultural University, Bikaner-334 006, India \\ *Corresponding author
}

\section{A B S T R A C T}

Keywords

Bottle gourd,

Seasonal incidence,

Bactrocera

cucurbitae, Abiotic factors

Article Info

Accepted:

07 November 2019

Available Online:

10 December 2019
An investigation was carried out on seasonal incidence of fruit fly, Bactrocera cucurbitae on bottle gourd and their correlation with abiotic factors at agronomy instructional farm, College of Agriculture, SKRAU Bikaner during summer, 2017 and 2018. The incidence of fruit fly observed in terms of per cent infestation on number and weight basis it caused to bottle guard fruits at three days interval during the crop period. The infestation of fruit fly observed on bottle gourd from third week of May. The peak infestation was recorded in first week of June while maximum and minimum temperature had significant positive correlation with fruit fly infestation. The morning and evening relative humidity had non significant correlation with the infestation of fruits due to fruit fly however; rainfall had non significant negative correlation.

\section{Introduction}

Bottle gourd is an important gourd having wide range of uses and is largely cultivated in the tropics and subtropics for its edible fruits. Tender fruits are used as vegetable and also for preparation of sweets and pickles especially in the hills. It has a cooling effect and prevents constipation and has diuretic and cardio-tonic properties. Fruit pulp is used as antidote against certain poisons. The cucurbits are subjected to damage by a wide array of insect-pests. major being, fruit fly (Rai et al., 2008, Sapkota et al., 2010) Fruit fly, B. cucurbitae is one of the most destructive pests often rendering cultivation of bottle gourd unprofitable.

The fruit are damaged by the maggots of this fly as the female fly lays its eggs in the tissues of fruits. The maggots feed on flesh and look like rotten fruits. The fruit fly also oviposits in 
tender plant tissues such as terminals, unopened flowers, young stems, roots, and seedlings. This may result in the death of the plant. So it was necessary to see the seasonal incidence of this pest on bottle gourd because Population density of insect pests and their natural enemies fluctuates with changing weather conditions. Abiotic factors regulate seasonal incidence, population count and development rates of the pests and natural enemies. As the cultivation of bottle gourd has expanded, the crop becomes susceptible to different environmental and biotic stress which has increased the pest infestations. Among these temperature and relative humidity play key role that regulates population dynamics, development rates and seasonal incidence of pest and their natural enemies. Such information is essential in developing integrated pest management systems with ecological and economical balance. Keeping this in view the experiment Seasonal Incidence of Fruit Fly, Bactrocera cucurbitae on bottle gourd and their correlation with abiotic factors were studied.

\section{Materials and Methods}

The studies on seasonal incidence of fruit fly Bactrocera cucurbitae On Bottle Gourd and Their Correlation with Abiotic Factors was carried out in the field condition at College Farm, College of agriculture, SKRAU, Bikaner during summer, 2017and 2018. The sowing of bottle guard variety Tharsamridhi was done on $8^{\text {th }}$ March in 2017 and $13^{\text {th }}$ March in 2018 in the plots measuring $10.0 \mathrm{~m} \times 10.0$ $\mathrm{m}^{2}$ keeping row to row and plant to plant distance of $2.50 \mathrm{~m}$ and $0.75 \mathrm{~m}$, respectively. There were four replications and all agronomic practices were followed as per recommendation of package of practices of Zone-IC. The incidence of fruit fly was estimated on the basis of per cent fruit infestation from fruit formation to last picking. The per cent infestation of fruit was worked out on weight and number basis. The infestation of fruits was calculated by picking fruits of marketable size at three days interval. The fruits of bottle gourd were examined and all fruits with fly punctures and healthy appearance were harvested. Through the crop season the crop was kept free from insecticides. Infested and healthy fruits were weighted and counted separately percentage of fruits damage on number and weight basis were worked out by the following formula (Preetha and Nadarajan, 2006).

Per cent infestation

(Number basis)

Total number of infested fruits

=-------------------------------X 100

Total number of picked fruits

Percent infestation

(Weight basis)

Total weight of infested fruits

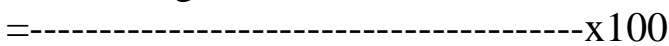

Total weight of picked fruits

Meteorological data regarding temperature (maximum and minimum), per cent relative humidity (morning and evening) and rainfall, were obtained from the meteorological observatory, Agriculture Research Station, Bikaner from March to June for both the years. Correlation coefficients (r-value) for incidence of fruit fly and abiotic factors responsible for seasonal variations were worked out.

\section{Results and Discussion}

The data on number basis fruit fly infestation presented in Table 1 inferred that during summer 2017, infestation of fruit fly started on bottle guard fruits during third week of May and it was 16.22 per cent. The infestation then increased gradually and reached to its peak $(50.53 \%)$ during first week of June thereafter it declined slightly to 20.88 per cent but could 
not observed below 20 per cent throughout season. In the consecutive year during summer, 2018, the incidence of fruit fly observed in terms of per cent infestation was commenced $(20.81 \%)$ in third week of May, which increased slightly to 21.45 per cent in the next three day of this week and reached its peak $(46.18 \%)$ in the first week of June. The per cent infestation of fruit fly showed declining pattern till last picking of fruits of bottle gourd in the last week of June (Table 1). For weight basis infestation, the data recorded during summer, 2017 presented in Table 2 revealed that fruit fly infestation $(17.05 \%)$ was first recorded in the third week of May.

Thereafter, it increased gradually and reached its peak $(39.25 \%)$ in first week of June. Later the infestation decreased gradually and reached at low level (19.25\%) during the fourth week of June. Similarly during summer, 2018 fruit fly infestation (18.48\%) was first recorded in the third week of May. It increased gradually and reached its peak $(48.61 \%)$ in the first week of June. After the peak infestation of fruit fly it showed decreasing pattern up to fourth week of June (Table 2).

The difference in the incidence may probably be due to the difference in sowing dates of the crop. Initially, the infestation was low but increased gradually reached to its peak during first week of June. Thereafter, the per cent infestation of fruit fly was showed declining pattern. The results are in agreement with those of Pareek and Kavadia (1986), Patnaik et al., (2004), Alim et al., (2012) who reported that peak incidence of this pest was observed in the month of May and June. Contrary to the present investigation Luskar and Chatterjee (2010) reported peak activity of fruit fly on cucurbitaceous crops during April, July and August. This may probably be due to difference in the dates of sowing. For Correlation between incidence of $B$. cucurbitae and abiotic factors on number basis infestation presented in Table 3 that during summer 2017, the incidence of fruit fly on bottle gourd started, when there was maximum temperature of $38.80^{\circ} \mathrm{C}$ and minimum temperature of $21.30^{\circ} \mathrm{C}$, relative humidity 64.00 and 22.00 per cent (morning and evening) and no rainfall. Peak fruit fly infestation of 50.53 per cent was recorded in first week of June with maximum and minimum temperature of 46.20 and $32.00^{\circ} \mathrm{C}$, respectively. While in summer 2018 during the incidence of fruit fly on bottle gourd started, when there was maximum temperature of $44.80^{\circ} \mathrm{C}$ and minimum temperature of $31.00^{\circ} \mathrm{C}$, relative humidity 33.00 and 17.00 per cent (morning and evening) and no rainfall. Peak fruit fly incidence of 46.18 per cent was recorded in first week of June with maximum and minimum temperature of 47.90 and $31.00^{\circ} \mathrm{C}$, respectively. The data presented in Table 3 and 4 revealed that the maximum temperature showed significant positive correlation $(r=0.5423$ and $r=0.5158$ with fruit fly) in both the years i.e. 2017 and 2018, respectively, whereas, minimum temperature had significant positive correlation (0.5221) with fruit fly infestation in summer, 2017 while it had non-significant positive correlation (0.3852) in summer, 2018.

It is evident from the data presented in table 4 on correlation between fruit fly infestation (on weight basis) and abiotic factors, in both the years i.e. summer 2017 and 2018 maximum temperature had significant positive correlation (0.5208and 0.5304 ,respectively) with fruit fly infestation. Minimum temperature showed significant positive correlation (0.6102 and 0.5310 , respectively) with fruit fly infestation, while relative humidity (morning and evening) showed nonsignificant negative correlation (-0.2863, 0.2795 and $-0.0191,-0.4034$, respectively during summer, 2017 and 2018) with fruit fly infestation. 
Table.1 Incidence of fruit fly, B. cucurbitae on bottle gourd during summer, 2017 and 2018 (number basis)

\begin{tabular}{lcccc}
$\begin{array}{c}\text { Dates of } \\
\text { observation }\end{array}$ & $\begin{array}{c}\text { Temperature } \\
\left({ }^{\circ} \mathrm{C}\right)\end{array}$ & $\begin{array}{c}\text { Relative } \\
\text { humidity } \\
(\%)\end{array}$ & $\begin{array}{c}\text { Total } \\
\text { rainfall } \\
(\mathrm{mm})\end{array}$ & $\begin{array}{c}\text { Fruit fly infestation }(\%) \\
\text { on no. basis }\end{array}$ \\
\cline { 1 - 3 } & Min. & Mor. Eve. &
\end{tabular}

\begin{tabular}{|c|l|l|l|l|l|l|}
\hline $\mathbf{2 0 1 7}$ & \multicolumn{5}{|l|}{} \\
\hline $\mathbf{1 7 - 0 5 - 1 7}$ & 38.8 & 21.3 & 64.0 & 22.0 & 0.20 & $\mathbf{1 6 . 2 2}$ \\
\hline $\mathbf{2 0 - 0 5 - 1 7}$ & 38.2 & 22.0 & 81.0 & 34.0 & 10.4 & $\mathbf{2 1 . 5 5}$ \\
\hline $\mathbf{2 3 - 0 5 - 1 7}$ & 41.2 & 27.5 & 63.0 & 31.0 & 3.20 & $\mathbf{2 6 . 3 0}$ \\
\hline $\mathbf{2 6 - 0 5}-17$ & 46.4 & 30.4 & 44.0. & 15.0 & 0.00 & $\mathbf{3 2 . 4 0}$ \\
\hline $\mathbf{2 9 - 0 5 - 1 7}$ & 44.9 & 27.0 & 73.0 & 35.0 & 0.00 & $\mathbf{3 8 . 4 6}$ \\
\hline $\mathbf{0 1 - 0 6 - 1 7}$ & 38.5 & 24.2 & 75.0 & 34.0 & 2.00 & $\mathbf{4 5 . 6 2}$ \\
\hline $\mathbf{0 4 - 0 6 - 1 7}$ & 46.2 & 32.0 & 59.0 & 45.0 & 0.00 & $\mathbf{5 0 . 5 3}$ \\
\hline $\mathbf{0 7 - 0 6 - 1 7}$ & 41.2 & 30.5 & 82.0 & 29.0 & 0.00 & $\mathbf{4 4 . 2 0}$ \\
\hline $\mathbf{1 0 - 0 6 - 1 7}$ & 41.3 & 28.3 & 47.0 & 26.0 & 0.00 & $\mathbf{3 8 . 8 5}$ \\
\hline $\mathbf{1 3 - 0 6 - 1 7}$ & 42.0 & 30.0 & 77.0 & 24.0 & 0.00 & $\mathbf{3 5 . 6 0}$ \\
\hline $\mathbf{1 6 - 0 6 - 1 7}$ & 39.4 & 30.2 & 89.0 & 38.0 & 0.00 & $\mathbf{3 3 . 5 7}$ \\
\hline $\mathbf{1 9 - 0 6 - 1 7}$ & 40.7 & 31.3 & 60.0 & 34.0 & 0.00 & $\mathbf{3 0 . 2 0}$ \\
\hline $\mathbf{2 2 - 0 6 - 1 7}$ & 33.8 & 18.0 & 92.0 & 60.0 & 24.8 & $\mathbf{2 5 . 5 4}$ \\
\hline $\mathbf{2 5 - 0 6 - 1 7}$ & 41.4 & 29.8 & 67.0 & 35.0 & 0.00 & $\mathbf{2 4 . 7 1}$ \\
\hline $\mathbf{2 8 - 0 6 - 1 7}$ & 32.4 & $\mathbf{2 4 . 0}$ & $\mathbf{9 4 . 0}$ & $\mathbf{6 4 . 0}$ & $\mathbf{2 1 . 6}$ & $\mathbf{2 0 . 8 8}$ \\
\hline
\end{tabular}

2018

\begin{tabular}{|c|c|c|c|c|c|c|}
\hline $\mathbf{1 5 - 0 5 - 1 8}$ & $\mathbf{4 4 . 8}$ & $\mathbf{3 1 . 0}$ & $\mathbf{3 3 . 0}$ & $\mathbf{1 7 . 0}$ & $\mathbf{0 . 0 0}$ & $\mathbf{2 0 . 8 1}$ \\
\hline $\mathbf{1 8 - 0 5 - 1 8}$ & 41.0 & 26.3 & 41.0 & 21.0 & 0.00 & $\mathbf{2 1 . 4 5}$ \\
\hline $\mathbf{2 1 - 0 5 - 1 8}$ & 43.6 & 27.5 & 26.0 & 14.0 & 0.00 & $\mathbf{2 8 . 6 5}$ \\
\hline $\mathbf{2 4 - 0 5 - 1 8}$ & 44.0 & 24.0 & 25.0 & 16.0 & 0.00 & $\mathbf{3 2 . 5 5}$ \\
\hline $\mathbf{2 7 - 0 5 - 1 8}$ & 45.8 & 25.5 & 21.0 & 9.00 & 0.00 & $\mathbf{4 1 . 5}$ \\
\hline $\mathbf{3 0 - 0 5 - 1 8}$ & 46.0 & 33.3 & 55.0 & 18.0 & 0.00 & $\mathbf{4 3 . 5 2}$ \\
\hline $\mathbf{0 2 - 0 6 - 1 8}$ & 47.9 & 31.0 & 33.0 & 13.0 & 0.00 & $\mathbf{4 6 . 1 8}$ \\
\hline $\mathbf{0 5 - 0 6 - 1 8}$ & 46.3 & 32.3 & 47.0 & 18.0 & 0.00 & $\mathbf{4 2 . 6 5}$ \\
\hline $\mathbf{0 8 - 0 6 - 1 8}$ & 43.8 & 32.8 & 53.0 & 15.0 & 0.00 & $\mathbf{4 1 . 2 1}$ \\
\hline $\mathbf{1 1 - 0 6 - 1 8}$ & 44.2 & 28.0 & 58.0 & 27.0 & 0.00 & $\mathbf{4 0 . 4 5}$ \\
\hline $\mathbf{1 4 - 0 6 - 1 8}$ & 39.8 & 28.5 & 66.0 & 29.0 & 0.00 & $\mathbf{3 6 . 2 5}$ \\
\hline $\mathbf{1 7 - 0 6 - 1 8}$ & 38.8 & 29.0 & 63.0 & 38.0 & 0.00 & $\mathbf{3 3 . 5 5}$ \\
\hline $\mathbf{2 0 - 0 6 - 1 8}$ & 42.5 & 28.5 & 73.0 & 30.0 & 0.00 & $\mathbf{3 3 . 2 5}$ \\
\hline $\mathbf{2 3 - 0 6 - 1 8}$ & 43.0 & 31.0 & 45.0 & 33.0 & 0.00 & $\mathbf{3 2 . 6}$ \\
\hline $\mathbf{2 6 - 0 6 - 1 8}$ & $\mathbf{4 0 . 0}$ & $\mathbf{2 3 . 5}$ & $\mathbf{6 9 . 0}$ & $\mathbf{4 1 . 0}$ & $\mathbf{1 5 . 8}$ & $\mathbf{3 0 . 8}$ \\
\hline
\end{tabular}


Table.2 Incidence of fruit fly, B. cucurbitae on bottle gourd during summer, 2017 and 2018 (weight basis)

\begin{tabular}{|c|c|c|c|c|c|c|}
\hline \multirow[t]{2}{*}{$\begin{array}{c}\text { Dates of } \\
\text { observation }\end{array}$} & \multicolumn{2}{|c|}{$\begin{array}{c}\text { Temperature } \\
\left({ }^{\circ} \mathrm{C}\right)\end{array}$} & \multicolumn{2}{|c|}{$\begin{array}{c}\text { Relative } \\
\text { Humidity } \\
(\%)\end{array}$} & \multirow[t]{2}{*}{$\begin{array}{l}\text { Total } \\
\text { rainfal } \\
\text { l }(\mathbf{m m})\end{array}$} & \multirow{2}{*}{$\begin{array}{c}\text { Fruit fly } \\
\text { infestation } \\
(\%) \\
\text { on weight } \\
\text { basis }\end{array}$} \\
\hline & Max. & Min. & Mor & Eve. & & \\
\hline \multicolumn{7}{|c|}{2017} \\
\hline 17-05-17 & 38.8 & 21.3 & 64.0 & 22.0 & 0.20 & 17.05 \\
\hline 20-05-17 & 38.2 & 22.0 & 81.0 & 34.0 & 10.4 & 17.37 \\
\hline 23-05-17 & 41.2 & 27.5 & 63.0 & 31.0 & 3.20 & 22.80 \\
\hline 26-05-17 & 46.4 & 30.4 & 44.0 & 15.0 & 0.00 & 28.43 \\
\hline 29-05-17 & 44.9 & 27.0 & 73.0 & 35.0 & 0.00 & 29.12 \\
\hline 01-06-17 & 38.5 & 24.2 & 75.0 & 34.0 & 2.00 & 29.78 \\
\hline 04-06-17 & 46.2 & 32.0 & 59.0 & 45.0 & 0.00 & 39.25 \\
\hline 07-06-17 & 41.2 & 30.5 & 82.0 & 29.0 & 0.00 & 36.65 \\
\hline 10-06-17 & 41.3 & 28.3 & 47.0 & 26.0 & 0.00 & 34.25 \\
\hline 13-06-17 & 42.0 & 30.0 & 77.0 & 24.0 & 0.00 & 33.80 \\
\hline 16-06-17 & 39.4 & 30.2 & 89.0 & 38.0 & 0.00 & 30.52 \\
\hline 19-06-17 & 40.7 & 31.3 & 60.0 & 34.0 & 0.00 & 26.47 \\
\hline 22-06-17 & 33.8 & 18.0 & 92.0 & 60.0 & 24.8 & 23.20 \\
\hline 25-06-17 & 41.4 & 29.8 & 67.0 & 35.0 & 0.00 & 22.62 \\
\hline 28-06-17 & 32.4 & 24.0 & 94.0 & 64.0 & 21.6 & 19.25 \\
\hline \multicolumn{7}{|c|}{2018} \\
\hline $15-05-18$ & 44.8 & 31.0 & 33.0 & 17.0 & 0.00 & 18.48 \\
\hline $18-05-18$ & 41.0 & 26.3 & 41.0 & 21.0 & 0.00 & 18.52 \\
\hline 21-05-18 & 43.6 & 27.5 & 26.0 & 14.0 & 0.00 & 24.61 \\
\hline 24-05-18 & 44.0 & 24.0 & 25.0 & 16.0 & 0.00 & 27.33 \\
\hline $27-05-18$ & 45.8 & 25.5 & 21.0 & 9.00 & 0.00 & 30.45 \\
\hline $30-05-18$ & 46.0 & 33.3 & 55.0 & 18.0 & 0.00 & 33.18 \\
\hline 02-06-18 & 47.9 & 31.0 & 33.0 & 13.0 & 0.00 & 48.61 \\
\hline 05-06-18 & 46.3 & 32.3 & 47.0 & 18.0 & 0.00 & $\mathbf{3 7 . 8 0}$ \\
\hline 08-06-18 & 43.8 & 32.8 & 53.0 & 15.0 & 0.00 & 36.85 \\
\hline $11-06-18$ & 44.2 & 28.0 & 58.0 & 27.0 & 0.00 & 34.68 \\
\hline 14-06-18 & 39.8 & 28.5 & 66.0 & 29.0 & 0.00 & 30.55 \\
\hline 17-06-18 & 38.8 & 29.0 & 63.0 & 38.0 & 0.00 & 29.80 \\
\hline $20-06-18$ & 42.5 & 28.5 & 73.0 & 30.0 & 0.00 & 25.45 \\
\hline 23-06-18 & 43.0 & 31.0 & 45.0 & 33.0 & 0.00 & 20.27 \\
\hline $26-06-18$ & 40.0 & 23.5 & 69.0 & 41.0 & 15.8 & 13.98 \\
\hline
\end{tabular}


Table.3 Correlation co-efficient (r-value) between incidence of fruit fly and abiotic factor during summer, 2017

\begin{tabular}{|c|c|c|c|}
\hline \multirow[t]{2}{*}{ S. No } & \multirow[t]{2}{*}{ Weather parameters } & \multicolumn{2}{|c|}{ Per cent incidence of fruit fly } \\
\hline & & Number basis & Weight basis \\
\hline $\mathbf{1}$ & Maximum temperature $\left({ }^{\circ} \mathrm{C}\right)$ & $0.5423^{*}$ & $0.5208^{*}$ \\
\hline 2 & Minimum temperature $\left({ }^{\circ} \mathrm{C}\right)$ & $0.5221^{*}$ & $0.6102^{*}$ \\
\hline 3 & Morning Relative humidity (\%) & -0.2051 & -0.2863 \\
\hline 4 & Evening Relative humidity (\%) & -0.1368 & -0.2795 \\
\hline 5 & Rainfall & -0.2947 & -0.3403 \\
\hline
\end{tabular}

*Significant at 5 per cent

Table.4 Correlation co-efficient (r-value) between incidence of fruit fly and abiotic factor during summer, 2018

\begin{tabular}{|c|c|c|c|}
\hline S. No & Weather parameters & \multicolumn{2}{|c|}{ Per cent incidence of fruit fly } \\
\hline $\mathbf{1}$ & Maximum temperature $\left({ }^{\circ} \mathrm{C}\right)$ & $0.5158^{*}$ & $\mathbf{0 . 5 3 0 4}$ \\
\hline $\mathbf{2}$ & Minimum temperature $\left({ }^{\circ} \mathrm{C}\right)$ & 0.3852 & $\mathbf{0 . 5 3 1 0}$ \\
\hline $\mathbf{3}$ & Morning Relative humidity & 0.0955 & $\mathbf{- 0 . 0 1 9 1}$ \\
\hline $\mathbf{4}$ & $\begin{array}{c}\text { Wvening Relative humidity } \\
(\%)\end{array}$ & -0.2393 & $\mathbf{- 0 . 4 0 3 4}$ \\
\hline $\mathbf{5}$ & Rainfall & - & - \\
\hline
\end{tabular}

*Significant at 5 per cent

Rainfall had non-significant negative correlation (-0.34.03) during summer, 2017. There was no rainfall during the 2018 of this experiment. Hence, correlation between fruit fly infestation and rainfall could not be analysed.

On the basis of results obtained during present investigation, it was observed that the maximum temperature showed significant positive correlation with incidence of fruit flyon number and weight basis, $\left(r=0.5423^{*}\right.$, $0.5158^{*}$ and $\left.0.5208^{*}, 0.5304 *\right)$ during 2017 and 2018. The present results are in conformity with those of Kate et al.,(2009), Laskar and Chatterjee (2010), Raghuwanshi et al.,(2012) and Bhowmik et al., (2014) who found a significant positive correlation with maximum temperature and incidence of fruit fly. Similarly, minimum temperature showed significant positive correlation with incidence of fruit fly in both the years.

These results corroborate with the findings of Kate et al., (2009), Laskar and chatterjee (2010) and Raghuwanshi et al., (2012) who reported that there was significant positive correlation with minimum temperature and incidence of fruit fly. The morning relative humidity showed non significant negative correlation with the incidence of fruit fly on number basis $(r=-0.2051$ and -0.0955$)$ and weight basis $(r=-0.2863$ and -0.0191$)$ in both the years 2017 and 2018. Similarly evening 
relative humidity also showed non significant negative correlation with the incidence of fruit fly on number basis $(\mathrm{r}=-0.1368$ and -0.2393 ) and weight basis $(r=-0.2795$ and -0.4034$)$ in both the years 2017 and 2018. These results are in conformity with those of Bhowmik et al., (2014) who reported non significant negative correlation with incidence of fruit fly and relative humidity Raghuwanshi et al., (2012) and Abro et al., (2017) reported non significant negative correlation with with incidence of fruit fly and morning relative humidity, also supports the present finding. The results obtained during the course of investigation indicated that the rainfall exhibited a non significant negative correlation with incidence of fruit fly in the year 2017. The present results are in agreement with those of Abu Manjar and Srivastav (2004) and Ravikumar and Viraktmath (2006) who reported non significant negative correlation, however, Banerjee et al., (2005) reported could not analysed correlation with rainfall and fruit fly population.

The incidence was observed in terms of infestation of fruits on number and weight basis due to fruit fly, started in third week of May and remained up to the fourth week of June on bottle gourd with peak activity in the first week of June during both the years. Maximum temperature and minimum temperature had significant positive correlation with incidence of fruit fly. However, a non significant negative correlation was found with the relative humidity and rainfall.

\section{References}

Abro, Z.A., Baloch, N., Khuhro, N.H., Qazi, W.A. and Saeed, N.A., 2017. Population densities of melon fruit fly Bactrocera cucurbitae (Coquillett) in vegetables agro-ecosystem in District
Hyderabad, Sindh, Pakistan. Sarhad Journal of Agriculture, 33(2): 331-337.

Alim, M. B., Hossain, M. A., Khan, M., Khan,

S. A. M., Islam, S. and Khalequzzaman, M. 2012. Seasonal variations of melon fly, Bactrocera cucurbitae (Coq.) (Diptera: Tephritidae) in different agricultural habitats of Bangladesh. ARPN Journal of Agricultural Biological Science, 7(11): 905-911.

Banerji, R., Sahoo, S.K., Das, S.K., Jha, S. 2005. Studies on incidence of melon fly, Bactrocera cucurbitae (Coq.) in relation to weather parameters on bitter gourd in new alluvial zone of West Bengal. Journal of Entomological Research, 29:179-82.

Bhowmik, P., Mandal, D. and Chatterjee, M.L. 2014. Chemical management of melon fruit fly, Bactrocera cucurbitae Conquillett (Diptera: Tephritidae) on Bitter Gourd (Momordica charantia Linn.) Pesticide Research Journal. 26(1): 68-73.

Kate, A.O., Bharodia., R.K., Joshi, M.D., Paradeshi, A.M. and Makadia, R. R. 2009. Seasonal incidence of fruit fly, Bactrocera cucurbitae (Coquillet) on cucumber. Asian Science. 4(12):83-84

Laskar, N. and Chatterjee, H. 2010. The effect of meteorological factors on the population dynamics of melon fly, Bactrocera cucurbitae (Coq.) (Diptera: Tephritidae) in the foot hills of Himalaya. Journal of applied sciences and environmental management. 14 (3): 53-58.

Pareek, B.L. and Kavadia, V.S. 1986. Seasonal incidence of insect pests on cucurbits in Rajasthan. Annals of Arid Zone, 25 (4):300-311.

Patnaik, HP, Sarangi, PK and Mahapatra, P., 2004. Studies on the incidence of fruit flies and jassids on summer bitter 
gourd and their control. Orissa Journal of Horticulture, 32(2): 87-90.

Preetha, H. and Nadarajan, L. 2006. Evaluation of IPM modules against bhendi fruit borer, Earias vittela (Fabricius) in Karaikal. Pest Management in Horticultural Ecosystem, 12 (2): 122-166.

Raghuvanshi, A.K., Satpathy, S. and Mishra, D.S. 2012. Role of abiotic factors on seasonal abundance and infestation of fruit fly, Bactrocera cucurbitae (Coquillet) on bitter gourd. Journal of Plant Protection Research. 52(10): 264-267.

Rai, M., Pandey, S. and Kumar, S. (2008). Cucurbit research in India: a retrospect. Proc. X EUCARPIA Meeting on Genetics and Breeding of Cucurbitacae, INRA, Avignan (France), May 21-24. pp.292-93.

Ravikumar, C.H. and Viraktamath, S. 2006. Influence of weather parameters on fruit fly trap catches in Dharwad, Karnataka. Pest Management in Horticultural Ecosystem, 12(2): 143151.

Sapkota, R., Dahal, K. C. and Thapa, R. B. (2010). Damage assessment and management of cucurbit fruit flies in spring-summer squash. J. Entomol. Nematol. 2: 7-12.

\section{How to cite this article:}

Meena, D. S., V. S. Acharya and Dinesh Kumar. 2019. Seasonal Incidence of Fruit Fly, Bactrocera cucurbitae on Bottle Gourd and their Correlation with Abiotic Factors. Int.J.Curr.Microbiol.App.Sci. 8(12): 381-388. doi: https://doi.org/10.20546/ijcmas.2019.812.051 